\title{
Generation of transgenic mice by transfection of pronuclear embryos using lipid-DNA complexes
}

\author{
Rosa Carballada*, Miguel Relloso* and Pedro Esponda \\ Centro de Investigaciones Biológicas, CSIC, Velázquez 144, 28006 Madrid, Spain
}

Date submitted: 6.3.02. Date accepted: 3.4 .02

\section{Summary}

\begin{abstract}
We had previously developed a methodology to introduce foreign DNA into mouse eggs and embryos using cationic lipids as vectors. In this report we use this technique to produce transgenic animals. Mouse embryos at the pronuclear stage were transfected using a mixture of a plasmid DNA, encoding for a nuclear form of $\beta$-galactosidase, and a commercial lipid transfection reagent. Embryos were washed and incubated overnight. Those that cleaved and develop to the 2-cell stage of normal appearance were transferred to the Fallopian tubes of pseudopregnant foster mothers. We analysed a total of 158 offspring and found two, a female and a male, to be transgenic (1.27\% of the total). Integration of the foreign DNA in the female was showed by Southern blot. Both animals expressed the lacz in several organs, but none of them either displayed expression in the germ cells or transmitted the transgene to their offspring. Taken together our results show that lipid transfection can generate transgenic mice, but the efficiency needs to be improved for this method to be widely applied.
\end{abstract}

Keywords: Liposomes, Mouse embryo, Transfection, Transgenics

\section{Introduction}

Transgenic technology has been a powerful tool in many areas of biomedical and biological research, as well as a major advance in biotechnology (Palmiter \& Brinster, 1986; Jaenisch, 1988). The most widespread method to produce transgenic animals is based on microinjection of the desired gene into the male pronucleus of the early embryo (Gordon, 1989). However, this method has some limitations. It requires expensive equipment, integration of the foreign genes is at random and, even in the mouse, the species in which the methodology has been standardised, the percentage of transgenic offspring is low (Brinster et al., 1985). This has brought about the necessity to develop alternative strategies that solve at least some of the problems.

The most relevant of the new methodologies, based on stem cell technology and gene targeting, is the pro-

All correspondence to: $\mathrm{Dr} \mathrm{P}$. Esponda, Centro de Investigaciones Biológicas, CSIC, Velázquez 144, 28006 Madrid, Spain. Tel: +34 915611800 (ext. 4336). Fax: +34 915627518. e-mail: esponda@cib.csic.es

*These two authors contributed equally to this work. duction of knockout mice (Evans \& Kaufman, 1981; Melton, 1994). In this case integration is not at random, which offers many advantages. However, efficiency is still low, the methods are both expensive and complicated and, in addition, the transgenic animals raised are chimaeric, so all the analyses need to wait for the second generation, once germ-line transmission has been tested. Moreover, there are species, such as dairy animals, in which stem cell lines have so far proved impossible to obtain (Mullins \& Mullins, 1996). In these species the percentage of transgenic animals obtained by the regular microinjection method can be as low as 1\% (Wall, 1997). Since dairy animals are often used as bioreactors in the pharmaceutical industry the need for new transgenic methodologies to apply to these species is crucial. In this regard some authors have reported the use of retroviruses (Jaenisch, 1976; Chan et al., 1998), adenoviruses defective in replication (Tsukui et al., 1996), internalisable ligand complexes (Ivanova et al., 1999), embryo pricking (Sato et al., 1993), sperm cells (Lavitrano et al., 1989) and more recently cloning by nuclear transfer (Wakayama et al., 1999) as alternatives to consider. 
Viruses are the best in terms of efficiency. Up to $100 \%$ of the infected embryos can express the recombinant protein, although when studying the offspring the percentage is reduced to about 20-30\% (Tsukui et al., 1996; Chan et al., 1998). Nevertheless, there are also some problems. Retroviruses do not infect well non-replicating cells. This causes a late integration of the transgene and a high number of mosaics. In addition, the size of the foreign DNA is quite limited. Adenoviruses have more capacity in terms of infection of non-dividing cells as well as insert size, but precautions must still be taken when handling infectious agents and in some cases the immunological defences of the host prevent correct expression of the transgene (Paillard, 1997). The use of sperm cells as vectors for foreign DNA seemed ideal because the method was simple and inexpensive. Nevertheless, it has also provoked a lot of criticism (Brinster et al., 1989) and so far it does not seem reliable enough to be widely applied. A modification of this method (Perry et al., 1999) that incorporates intracytoplasmic sperm injection (ICSI) has been demonstrated to be more predictable, giving rise to almost $30 \%$ of transgenic mice. However, the technique is even more complicated than the traditional pronuclear microinjection, which is a severe limitation. Cloning has proved the best for transgenic production in livestock (Schnieke et al., 1997; Kuhholzer \& Prather, 2000) although the efficiencies are still poor.

We have previously shown that lipid delivery systems can be useful for introducing foreign DNA into oocytes and early embryos (Carballada et al., 2000). This system has many advantages: it is simple, inexpensive and the percentage of expression found in blastocysts is quite comparable to those obtained by other methods. In this report we evaluate the usefulness of the transfection of mouse pronuclear embryos with lipid-DNA complexes as an alternative procedure for generating transgenic mice.

\section{Materials and methods}

\section{Collection of mouse eggs and embryos}

F1 $(\mathrm{C} 57 \mathrm{bl} \times \mathrm{CBA})$ females were used as source of embryos. The females were induced to superovulate by an intraperitoneal injection of $5 \mathrm{IU}$ pregnant's mare serum gonadotropin (PMSG) followed by 5 IU human chorionic gonadotropin (hCG) $48 \mathrm{~h}$ later. The females were allowed to mate at libitum with vigorous stud males of CD-1 strain and were then killed the following morning to retrieve the pronuclear embryos from the oviductal ampullae.

\section{Transfection procedures}

The methods employed were those described previously (Carballada et al., 2000). Briefly, the isolated embryos were treated for 1-2 min in acidic Tyrode solution (Sigma) to permeabilise the zona pellucida, and were then exhaustively washed in M2 and transferred to $100 \mu \mathrm{l}$ microdrops of M2 containing the mixture of DNA Fugene under mineral oil. The plasmid used for the transfection was a construct containing a nuclear form of the enzyme lacz. It was prepared by insertion of the BamHI/XbaI fragment of pCS2+-nls $\beta$ gal (a generous gift from Dr R. Rupp, Tübingen, Germany) into the plasmid pd2EGFP (Clontech) in which the GFP had been excised using the same enzymes. This resulted in a plasmid with the lacz under the control of the CMV/IE promoter/enhancer element and with SV40 polyA. The plasmid was digested with $B \ln \mathrm{I}$ giving two fragments of $6.3 \mathrm{~kb}$ and $1 \mathrm{~kb}$. The former was used for transfection; $500 \mathrm{ng}$ in combination with $1 \mu \mathrm{l}$ of Fugene (Roche) were resuspended in $100 \mu \mathrm{l}$ of M2. Transfection was allowed to proceed for $3 \mathrm{~h}$ at $37{ }^{\circ} \mathrm{C}$ in an atmosphere of $5 \% \mathrm{CO}_{2}$. Then, the embryos were washed in M2 and left in the incubator overnight.

\section{Embryo transfer and analyses of the offspring}

The embryos that cleaved regularly were transferred to the Fallopian tubes of pseudopregnant foster mothers of the CD-1 strain. Typically, 20-30 embryos were transferred to each female. The offspring were left undisturbed until weaning and then genomic DNA was obtained from tail biopsies following standard procedures. The DNA was tested by polymerase chain reaction (PCR), slot blot and Southern blot for the presence of the transgene. Positive animals were allowed to mate three times. They were then killed and their organs used for histochemical detection of $\beta$-galactosidase. Their offspring were analysed following the same procedures just described.

\section{PCR analyses}

Two hundred nanograms of genomic DNA was used as a template for PCR amplification. The primers used for lacz detection were 5'-CGTCGTTTTACAACGTCGTGA-3' prime and 5'-ATGTGAGCGAGTAACAACCCGTCGGATTCT-3', which amplify a $356 \mathrm{bp}$ fragment. Two hundred nanograms of each sample were also tested for a PCR using the following primers: 5'-TACCACAGGCATTGTGATGG-3' and 5'-AATAGTGATGACCTGGCCGT-3', which amplify a $310 \mathrm{bp}$ fragment of the $\beta$-actin gene. Conditions for the PCR were identical for the two sets of reactions: 35 cycles of $95^{\circ} \mathrm{C}(30 \mathrm{~s}), 55^{\circ} \mathrm{C}(30 \mathrm{~s})$ and $72{ }^{\circ} \mathrm{C}(1 \mathrm{~min})$. 
The PCR reaction was run in a $1 \%$ agarose gel, stained with ethidium bromide and examined and photographed under ultraviolet (uv) light.

\section{Slot and Southern blot analyses}

Ten micrograms of genomic DNA per mouse was blotted onto a $0.2 \mu \mathrm{m}$ pore nitrocellulose filter using a BioDot SF Microfiltration Apparatus (BioRad, Hercules, CA) and subsequently UV-crosslinked. The filter was incubated in $2 \times$ SSC (Sambrook et al., 1989) for $3 \mathrm{~h}$ at 55 ${ }^{\circ} \mathrm{C}$ in hybridisation solution $(50 \% \mathrm{v} / \mathrm{v}$ deionised formamide, 3.2\% SDS, $5 \times$ Denhardt's solution, $100 \mu \mathrm{g} / \mathrm{ml}$ herring sperm DNA and $5 \times$ SSC). Then, the filter was incubated overnight at $55^{\circ} \mathrm{C}$ in $5 \mathrm{ml}$ of fresh solution containing $50 \mathrm{ng}$ of the DIG-labelled probe. The probe was prepared using the $\mathrm{BamHI} / \mathrm{XbaI}$ fragment of the plasmid (that contains the nls- $\beta$ gal sequence) and the DIG DNA labelling kit from Roche (Basel, Switzerland). The filter was washed thoroughly in $2 \times$ SSC at $60{ }^{\circ} \mathrm{C}$ and then rinsed in phosphate-buffered saline (PBS). The presence of DIG-labelled DNA was detected by the use of the digoxigenin detection reagents and protocols provided by Roche. Briefly, the filter was rinsed in PBS, incubated for $30 \mathrm{~min}$ in blocking solution and then for $2 \mathrm{~h}$ in anti-DIG antibody conjugated to alkaline phosphatase. The positive signal was revealed using a chemoluminescent substrate (CDP-Star, Roche) diluted 1:200 in AP buffer (100 mM Tris, $100 \mathrm{mM} \mathrm{NaCl}$ and $50 \mathrm{mM} \mathrm{MgCl}$; $\mathrm{pH}$ 9.5) and an X-OMAT AR film (Kodak).

For Southern blot analyses, $20 \mu \mathrm{g}$ of genomic DNA was digested with the enzyme BamHI, electrophoresed in a $1 \%$ agarose gel and blotted onto a $0.2 \mu \mathrm{m}$ pure nitrocellulose filter. The DNA was hybridised to the random-primed digoxigenin-labelled probe and detection of the transgene was carried out by the same procedures described above.

\section{Histochemical detection of $\beta$-galactosidase}

The method employed was similar to that described by Tsukui et al. (1996). Briefly, several mouse tissues were extracted and fixed for $1 \mathrm{~h}$ in $0.5 \%$ paraformaldehyde, $2.5 \%$ glutaraldehyde in PBS. The fixed samples were washed three times in washing buffer (PBS containing $0.01 \%$ sodium deoxycholate, $0.02 \%$ Nonidet P40 and $2 \mathrm{mM} \mathrm{MgCl}_{2}$ ) and then washed once in the X-gal buffer (washing buffer containing $30 \mathrm{mM}$ of $\mathrm{K}_{3} \mathrm{Fe}(\mathrm{CN})_{6}$ and $30 \mathrm{mM}$ of $\left.\mathrm{K}_{4} \mathrm{Fe}(\mathrm{CN})_{6}\right)$. The tissues were stained by overnight incubation at $37{ }^{\circ} \mathrm{C}$ in $0.8 \mathrm{mg} / \mathrm{ml} \mathrm{X-gal}$ (Sigma, St Louis, MO) in X-gal buffer. After thorough washing, samples were postfixed in $4 \%$ paraformaldehyde overnight at $4{ }^{\circ} \mathrm{C}$ and observed and photographed using a Nikon stereomicroscope. Some pieces of tissues were also processed for cryostat sectioning.
Ten micrometre sections were counterstained with a Neutral Red solution and observed and photographed under bright-field microscopy. Controls including tissue from the non-transgenic littermates were included in all analyses.

\section{Results}

A total of 856 2-cell embryos were transferred to 29 pseudopregnant females giving rise to 158 offspring. Two of them, a female and a male, were transgenic, as judged by PCR analysis (Fig. 1). This represents $1.27 \%$ of transgenic animals. The results were confirmed by slot blot (Fig. 2). This technique was also used to estimate the number of copies. The female seemed to have a single copy, while the male showed less than one copy, suggesting mosaicism (Figs. 2a-c). Southern blot analyses showed integration of the transgene in

\section{$\beta$-gal}

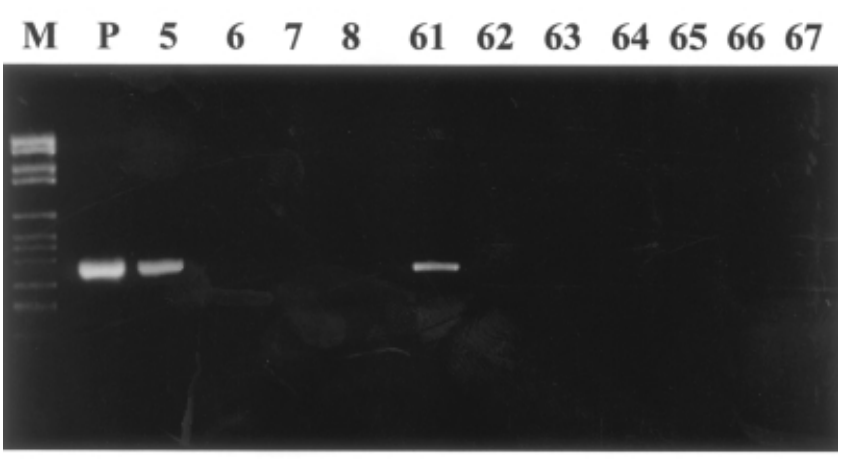

\section{$\beta$-actin}

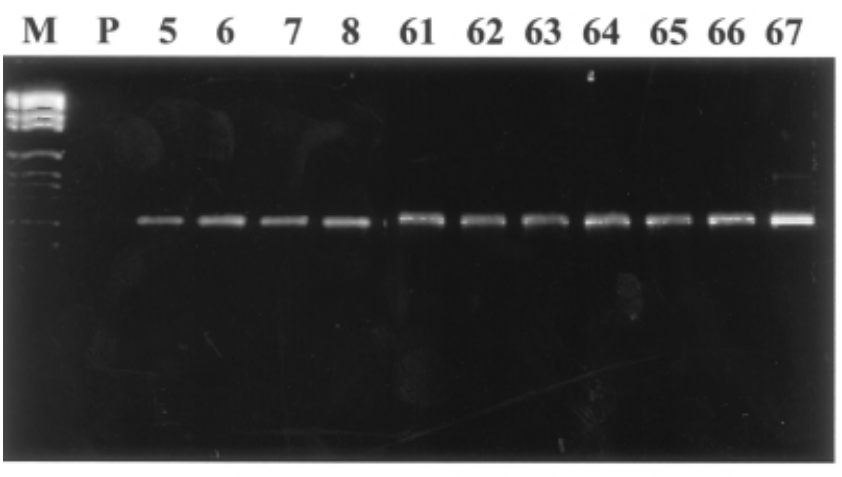

Figure 1 Detection of the transgene in the offspring by PCR. The upper panel shows the detection of the lacz gene, while the lower shows detection of the $\beta$-actin that was used as control. M, molecular weight markers (Roche no. VI); P, plasmid (positive control). Numbers represent different mice: $5-8$ are females, 61-67 are males. A clear amplification band for the lacz gene is shown in frame 5 and male 61. 
(a)

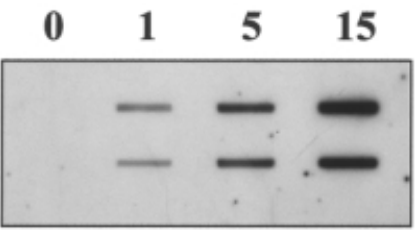

(b)

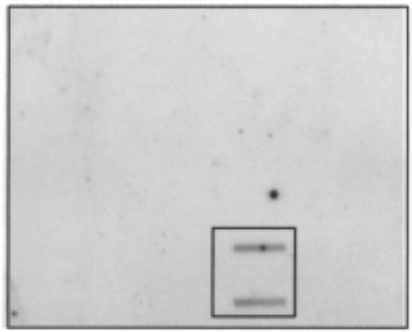

(c)

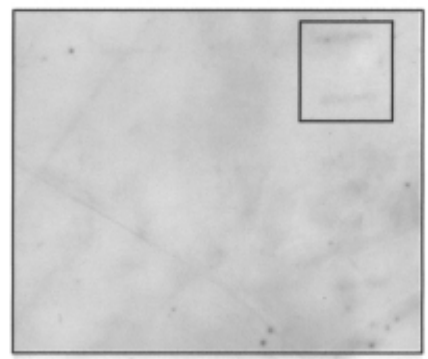

(d)

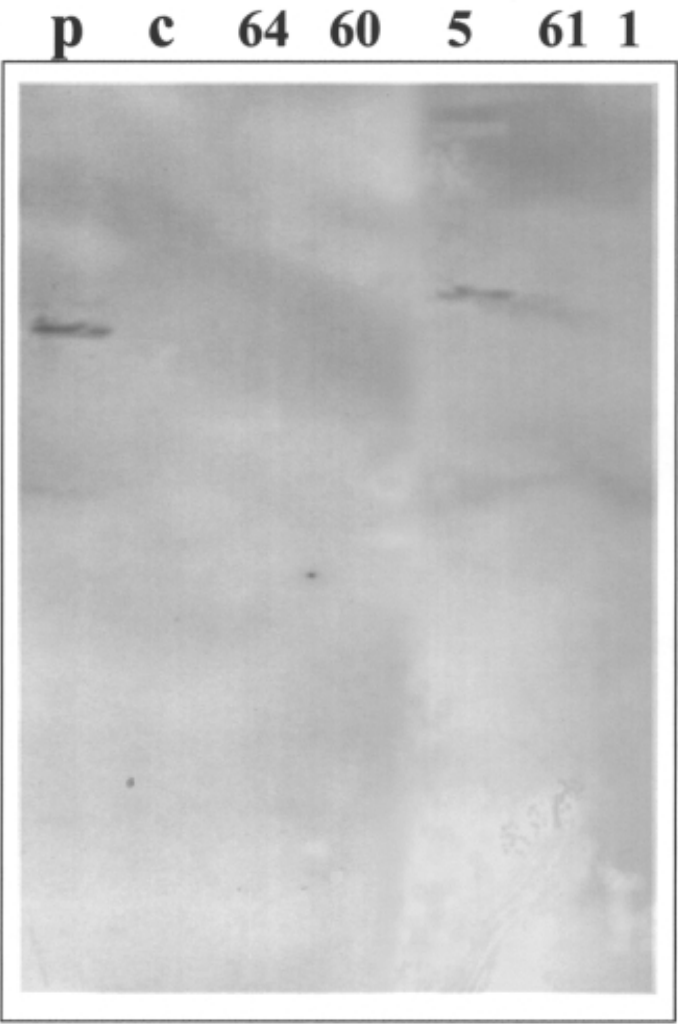

Figure 2 Detection of the transgene by slot blot $(b, c)$ and Southern blot $(d)$. (a) Scale to determine the number of copies of the transgene present in the genomic DNA. Different amounts of the plasmid encoding the lacz were loaded by duplicate. They were the equivalent to 1, 5 or 15 copies of the gene. (b) Slot blot using genomic DNA obtained from tail biopsies of some mice. All samples were loaded in duplicate. One positive (female 5) is enclosed in the square. Comparison of the band intensities with the scale (a) allows us to assign one copy of the gene to this animal. (c) Slot blot using genomic DNA from a different litter. One faint positive (male 61) is indicated. The intensity is equal to less than one copy. (d) Southern blot analysis of genomic DNA obtained from tail biopsies of the putative transgenic mice. All DNA samples were digested with BamHI. The probe hybridised only with the lacz sequence. p, plasmid (the linear fragment used for transfection was digested with Bam HI); $\mathrm{c}$, negative control (another plasmid). Numbers indicate different mice. A clear positive band of about $6 \mathrm{~kb}$ and a fainter one of more than 10 $\mathrm{kb}$ can be seen in female 5 . The probe recognises a fragment of $4.3 \mathrm{~kb}$ in the control plasmid.

the host genome (Fig. $2 d$ ) for the case of the female. The male gave no signal, but this can be indicative of a low amount of foreign DNA.

Neither the female nor the male transmitted the transgene to their offspring, showing that no integration in the germline had taken place. When their tissues were analysed to detect $\beta$-galactosidase expression, we confirmed that they were both chimaeric. The pattern of expression in the different tissues is recorded in Table 1 . While the female showed expression in five organs and in the placenta of some fetuses, the male had positive cells only in the liver, forebrain and testes (Fig. 3). In the latter, X-gal staining was restricted to the interstitial tissues (Fig. $3 h)$, which is in agreement with the lack of germline transmission of the foreign gene. Accordingly, in the female no positive blue nucleus was detected in the ovaries.

Table 1 Expression pattern of the lacz transgene in the different organs and tissues of the transgenic mice

\begin{tabular}{llllllllllllll}
\hline & Brain & Cerebellum & Kidney & Liver & Pancreas & Spleen & Heart & Gut & Skin & Muscle & $\begin{array}{c}\text { Gonads } \\
\text { tract }\end{array}$ \\
\hline Female 5 & + & + & & - & - & + & - & - & + & - & - & - \\
Male 61 & + & - & - & + & - & - & - & - & - & - & + \\
\hline
\end{tabular}




\section{Discussion}

Lipid-DNA complexes have been used successfully to transfect different cell lines (Uduehi et al., 1999; Fronsdal et al., 2000). Moreover, they have also been useful to transfect organs in vivo (Cuevas et al., 1996; Anderson, 1998; Relloso \& Esponda, 2000; Hyde et al., 2000). Lipid delivery systems have many advantages: they are easy to use and have no limitations regarding the size of foreign DNA that can be introduced. The major hindrance is related to the variability in the transfection rate among different cells and the low integration frequency, in the range of $10^{-3}-10^{-5}$ (Deshayes et al., 1985; Gubin et al., 1999). We had previously shown that mouse eggs and embryos are easily transfected (Carballada et al., 2000), so the only concern when using this technique to generate transgenic mice would be a low integration rate. Our present results show that, actually, this rate is low $(1.27 \%)$. Nevertheless, in comparison with the percentages described for cultured cells, it is relatively high. Since the methodology is simple and allows the handling of a huge number of embryos, this problem could be overcome. Nevertheless, we also found a high incidence of mosaicism and this is more worrisome. This result was not surprising, since we had already reported 30\% chimaeric blastocysts when transfecting pronuclear embryos (Carballada et al., 2000), but in combination with the low integration frequency it poses a serious obstacle to the generation of transgenic mice lines by this procedure. This problem could be associated with the use of the liposome systems, since the lipid-DNA complexes are incorporated first into the cytoplasm and need some time to reach the nucleus (Higashi \& Sunamoto, 1995). However, it is not unique to our system. Sperm delivery of foreign DNA must also occur into the cytoplasm, unless the genes undergo prior integration in the highly compacted sperm nucleus, which is not likely. In fact, this could explain why, while many laboratories have obtained transgenic embryos using spermatozoa as vectors for the DNA, few have reported the establishment of transgenic lines (Smith, 1999). Retroviral infection of embryos also gives rise to mosaic fetuses and adults (Rubenstein et al., 1986), a problem that could be related to the fact that the viruses cannot infect nondividing cells (Miller et al., 1990), so the integration happens in the dividing embryo and only in some cells. But, even when using the traditional microinjection procedure only a low percentage of embryos, around $21 \%$, integrate the transgene in all the blastomeres (Chan et al., 1999), so the problem is more complex.

We saw effective integration in the female, but failed to demonstrate it in the male. A possible explanation is that in the male the foreign DNA is present as an episome. Episomal maintenance has already been described on some rare occasions (Rassoulzadegan et al., 1986; Elbrecht et al., 1987). We are more inclined, though, to accept that it is integrated, but in such a small number of cells that its visualisation is very difficult. This is supported by the fact that the slot blot gave a faint signal, equivalent to less than one copy, as well as by the expression pattern of the lacz, which was more restricted than in the female. Expression of lacz for the two mice was not ubiquitous and while one can speculate about inactivation of the foreign gene by methylation (Jaenisch et al., 1982) or attenuation of the viral promoter (Paillard, 1997), the simplest interpretation is that the expression pattern is reflecting DNA integration.

In general, we still think that lipid transfection of mouse embryos could be a useful method to generate transgenic animals, but the integration efficiencies need to be improved and the incidence of mosaicism reduced. An impending necessity in the field is to develop strategies that favour the early integration and homogeneous expression of the transgene. Several methodologies have been used in vertebrate embryos other than the mouse, which could be assayed. These include the use of the nuclear localisation signal peptide in combination with the DNA (Liang et al., 2000), the use of constructs containing the ITRs (inverted terminal repeats) of certain viruses (Fu et al., 1998) or socalled restriction enzyme mediated-integration or REMI (Kroll \& Amaya, 1996). We are currently testing some of these to see whether there is a significant improvement.

In summary, the results obtained so far show that transfection of the mouse embryo can be used to obtain transgenic mice. Nevertheless, the low frequencies of transgenic animals and the high incidence of chimaerism are points that must be addressed before this methodology can be widely applied.

\section{Acknowledgements}

We are grateful to A. González for her invaluable help in doing the cryosections. This work was partially supported by grant BCM2000-0899 from CICYT (Spain).

\section{References}

Anderson, W.F. (1998). Human gene therapy. Nature 392, 25-30.

Brinster, R.L., Chen, H.Y., Trumbauer, M.E., Yagle, M.K. \& Palmiter, R.D. (1985). Factors affecting the efficiency of introducing foreign DNA into mice by microinjecting eggs. Proc. Natl. Acad. Sci. USA 82, 4438-42.

Brinster, R.L., Sandgren, E.P., Behringer, R.R. \& Palmiter, R.D. (1989). No simple solution for making transgenic mice. Cell 59, 239-41. 

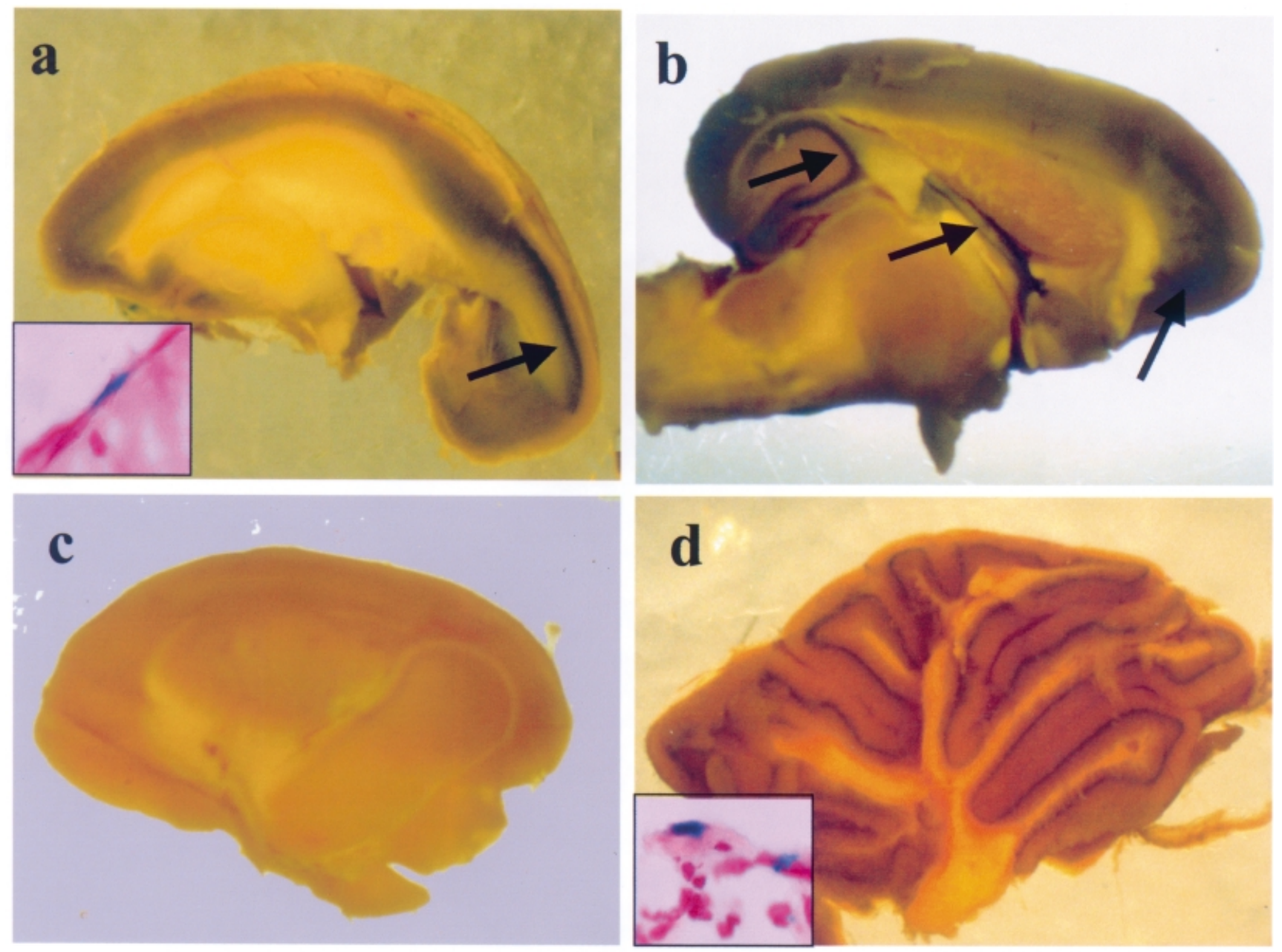

Figure 3 Expression pattern of the lacz transgene in organs and tissues of the transgenic mice. (a), Whole mount of the brain of female 5. The arrow indicates one of the most stained areas. Magnification $\times 7.5$. One stained nucleus in the tissue section is shown in the inset (magnification $\times 500)$. ( $b$ Whole mount of the brain of male 61 . Three areas of blue nuclei can be distinguished and are indicated by arrows. Magnification $\times 7.5$. (c) Whole mount of the brain of a nontransgenic littermate (female 64). No blue stained areas are apparent. Magnification $\times 7$. (d) Whole mount of the cerebellum of female 5. A line of stained nuclei is clearly seen. Magnification $\times 8$. Two stained nuclei in the tissue section are shown in the inset (magnification $\times 400)$. $(e)$ Whole mount of the cerebellum of a non-transgenic littermate (female 64). No blue stained areas are seen. Magnification $\times 7$. $(f)$ Section of the liver of male 61 . Some blue nuclei are interspersed among non-stained ones. The tissue is counterstained with a Neutral Red solution. Scale bar represents $25 \mu \mathrm{m}$. $(\mathrm{g})$ Section of the uterus of female 5 . The female was pregnant when killed, so the uterine wall is heavily decidualised. A high number of blue nuclei are found among the stromal cells. Scale bar represents 50 $\mu \mathrm{m}$. (h) Section of the testes from male 61. Blue nuclei are restricted to the interstitial tissue. Scale represents $50 \mu \mathrm{m}$.

Carballada, R., Degefa, T. \& Esponda, P. (2000). Transfection of mouse eggs and embryos using DNA combined to cationic liposomes. Mol. Reprod. Dev. 56, 360-5.

Chan, A.W., Homan, E.J., Ballou, L.U., Burns, J.C. \& Bremel, R.D. (1998). Transgenic cattle produced by reverse-transcribed gene transfer in oocytes. Proc. Natl. Acad. Sci. USA 95, 14028-33.

Chan, A.W.S., Kukolj, G., Shalka, A.M. \& Bremel, R.D. (1999). Timing of DNA integration, transgenic mosaicism and pronuclear injection. Mol. Reprod. Dev. 52, 406-13.

Cuevas, P., Garcia-Calvo, M., Carcellar, F., Reimers, D., Zazo, M., Cuevas, B., Munoz-Willery, I., Martinez-Coso, V., Lamas, S. \& Gimenez-Gallego, G. (1996). Correction of hypertension by normalization of endothelial levels of fibroblast growth factor and nitric oxide synthase in spontaneously hypertensive rats. Proc. Natl. Acad. Sci. USA 93, 11996-12001.

Deshayes, A., Herrera-Estrella, L., \& Caboche, M. (1985). Liposome-mediated transformation of tobacco mesophyll protoplasts by an Escherichia coli plasmid. EMBO J. 4, 2731-7.

Elbrecht, A., DeMayo, F.J., Tsai, M.J. \& O'Malley, B.W. (1987). Episomal maintenance of a bovine papilloma virus vector in transgenic mice. Mol. Cell Biol. 7, 1276-9.

Evans, M.J. \& Kaufman, M.H. (1981). Establishment in culture of pluripotential cells from mouse embryos. Nature 292, 154-6.

Fronsdal, K., Engedal, N. \& Saatcioglu, F. (2000). Efficient 

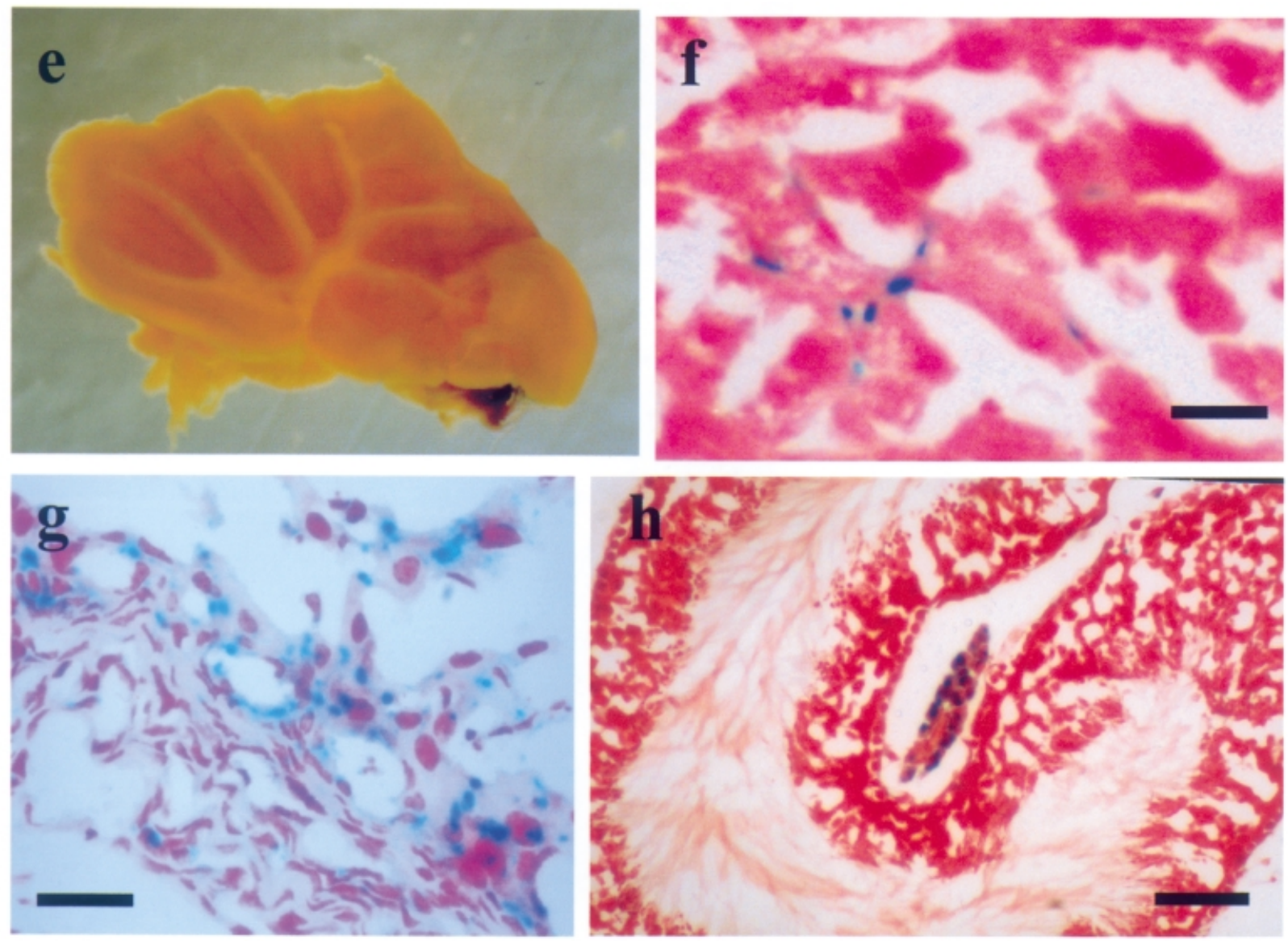

Figure 3 Continued

DNA-mediated gene transfer into prostate cancer cell line LNCaP. Prostate 43, 111-17.

Fu, Y., Wang, Y. \& Evans, S.M. (1998). Viral sequences enable efficient and tissue-specific expression of transgenes in Xenopus. Nat. Biotechnol. 16, 253-7.

Gordon, J.W. (1989). Transgenic animals. Int. Rev. Cytol. 115, 171-229.

Gubin, A.N., Koduru, S., Njoroge, J.M., Bhatnagar, R. \& Miller, J.L. (1999). Stable expression of green fluorescent protein after liposomal transfection of K562 cells without selective growth conditions. Biotechniques 27, 1162-70.

Higashi, N. \& Sunamoto, J. (1995). Endocytosis of poly(ethylene oxide)-modified liposome by human lymphoblastoid cells. Biochim. Biophys. Acta 1243, 386-92.

Hyde, S.C., Southern, K.W., Gileadi, Y., Fitzjohn, E.M., Moffard, K.A., Waddell, B.E., Gooi, H.C., Goddard, C.A., Hannavy, K., Smyth, S.E., Egan, J.J., Sorgi, F.L., Huang, L., Cuthbert, A.W., Evans, M.J., Colledge, W.H., Higgins, C.F., Webb, A.K. \& Gill, D.R. (2000). Repeat administration of DNA/liposomes to the nasal epithelium of patients with cystic fibrosis. Gene. Ther. 7, 1156-65.

Ivanova, M.M., Rosenkranz, A.A., Smirnova, O.A., Nikitin, V.A., Sobolev, A.S., Landa, V., Naroditsky, B.S. \& Ernst, L.K. (1999). Receptor-mediated transport of foreign DNA into preimplantation mammalian embryos. Mol. Reprod. Dev. 54, 112-20.

Jaenisch, R. (1976). Germ line integration and mendelian transmission of the exogenous Moloney leukaemia virus. Proc. Natl. Acad. Sci. USA 73, 1260-4.

Jaenisch, R. (1988). Transgenic animals. Science 240, 1468-74. Jaenisch, R., Harbers, K., Jahner, D., Stewart, C. \& Stuhlmann, H. (1982). DNA methylation, retroviruses, and embryogenesis. J. Cell Biochem. 20, 331-6.

Kroll, K.L. \& Amaya, E. (1996). Transgenic Xenopus embryos from sperm nuclear transplantations reveal FGF signalling requirements during gastrulation. Development 122, 3173-83.

Kuhholzer, B. \& Prather, R.S. (2000). Advances in livestock nuclear transfer. Proc. Soc. Exp. Biol. Med. 224, 240-45.

Lavitrano, M., Camaioni, A., Fazio, V.M., Dolci, S., Farace, M.G. \& Spadafora, C. (1989). Sperm cells as vectors for introducing foreign DNA into eggs: genetic transformation of mice. Cell 57, 717-23.

Liang, M.R., Alestrom, P. \& Collas, P. (2000). Glowing zebrafish: integration, transmission, and expression of a single luciferase transgene promoted by noncovalent DNA-nuclear transport peptide complexes. Mol. Reprod. Dev. 55, 8-13.

Melton, D.W. (1994). Gene targeting in the mouse. Bioessays 16, 633-8.

Miller, D.G., Adam, M.A. \& Miller, A.D. (1990). Gene transfer by retrovirus vectors occurs only in cells that are actively replicating at the time of infection. Mol. Cell Biol. 10, 4239-42. 
Mullins, L.J. \& Mullins, J.J. (1996). Transgenesis in the rat and larger mammals. J. Clin. Invest 97, 1557-60.

Paillard, F. (1997). Promoter attenuation in gene therapy: causes and remedies. Hum. Gene Ther. 8, 2009-10.

Palmiter, R.D. \& Brinster, R.L. (1986). Germ-line transformation of mice. Annu. Rev. Genet. 20, 465-99.

Perry, A.C., Wakayama, T., Kishikawa, H., Kasai, T., Okabe, M., Toyoda, Y. \& Yanagimachi, R. (1999). Mammalian transgenesis by intracytoplasmic sperm injection. Science 284, 1180-3.

Rassoulzadegan, M., Leopold, P., Vailly, J. \& Cuzin, F. (1986). Germ line transmission of autonomous genetic elements in transgenic mouse strains. Cell 46, 513-19.

Relloso, M. \& Esponda, P. (2000). In-vivo transfection of the female reproductive tract epithelium. Mol. Hum. Reprod.6, 1099-105.

Rubenstein, J.L., Nicholas, J.F. \& Jacob, F. (1986). Introduction of genes into preimplantation mouse embryos by use of a defective recombinant retroviruses. Proc. Natl. Acad. Sci. USA 83, 366-8.

Sambrook, J., Fritsch, E.F. \& Maniatis, T. (1989). Analysis of genomic DNA by Southern hybridization. In Molecular Cloning: A Laboratory Manual, vol. 2, pp. 9.31-9.62. Cold Spring Harbor: Cold Spring Harbor Laboratory Press.
Sato, M., Tada, N., Iwase, R. \& Amann, E. (1993). Gene introduction into mouse blastocysts via 'pricking'. Mol. Reprod. Dev. 34, 349-56.

Schnieke, A.E., Kind, A.J., Ritchie, W.A., Mycock, K., Scott, A.R., Ritchie, M., Wilmut, I., Colman, A. \& Campbell, K.H. (1997). Human factor IX transgenic sheep produced by transfer of nuclei from transfected fetal fibroblasts. Science 278, 2130-3.

Smith, K.R. (1999). Sperm cell mediated transgenesis: a review. Anim. Biotech. 10, 1-13.

Tsukui, T., Kanagae, Y., Saito, I. \& Toyoda, Y. (1996). Transgenesis by adenovirus-mediated gene transfer into mouse zona-free eggs. Nat. Biotechnol. 14, 982-5.

Udeuhi, A.N., Moss, S.H., Nuttall, J. \& Pouton, C.W. (1999). Cationic lipid-mediated transfection of differentiated Caco-2 cells: a filter culture model of gene delivery to a polarized epithelium. Pharm. Res. 16, 1805-11.

Wakayama, T., Rodriguez, I., Perry, A.C., Yanagimachi, R. \& Mombaerts, P. (1999). Mice cloned from embryonic stem cells. Proc. Natl. Acad. Sci. USA 96, 14984-9.

Wall, R.J. (1977). A new lease on life for transgenic livestock. Nat. Biotechnol. 15, 416-17. 